\title{
ЗАМІСТЬ ПЕРЕАМОВИ
}

INSTEAD OF A PREFACE

УДК 58.006: 502.75

DOI 10.37555/2707-3114.1.2021.247346

\section{«Софіївка» - шедевр садово-паркового мистецтва 18-19 сторічь на 225-році від ії заснування}

Іван С. Косенко

Наџіональний дендрологічний парк «Софіївка» НАН України, м. Умань, Черкаської обл., Україна, E-mail: ndp.sofievka@gmail.com

\section{"Sofiyivka" - a masterpiece landscape design of 18-19 centuries on 225th anniversary of its founding}

Ivan S. Kosenko

National dendrological park “Sofiyivka” of NAS of Ukraine, E-mail: ndp.sofievka@gmail.com

Meта. Національний дендрологічний парк «Софіївка» Наџіональної академії наук України (НДП «Софіївка»), який розташований у м. Умань, Черкаської області, широко відомий далеко за межами України як одне з найвидатніших творінь світового садово-паркового мистеџтва кінця XVIII-першої половини XIX ст.

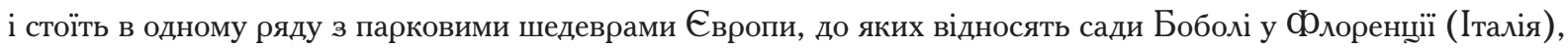
парк Сансусі в Потсдамі (Німеччина) і Палаџовий парк у Версалі (СОанџія).

Всю історію заснування, будівниџтва і розвитку «Софї̈вки» можна умовно поділити на сім періодів. Протягом першого періоду (1796-1832) парк був власністю родини Потоџьких і всі роботи здійснювалися під безпосереднім керівниџтвом Станіслава і Софії Потоџьких і їхніх спадкоємџів. Другий період (1832 1836) пов'язаний з перебуванням «Софї̈вки» у державній власності під патронатом Київської державної палати у відповідності з џарським указом 1832 р., за яким парк «Софіївка» (як і вся власність Потоџьких), був конфіскований. Третій період (1836-1859) розпочався також за џарським указом. 21 квітня 1836 року імператор Микола І вказав: «... повелеваю иислить Сад сей собственностью Ея Императорского Величества, именуя его впредь Џариџыным» (Величенко, 2006). Початок четвертого періоду (1859-1929) декретовано указом імператора Олександра II від 30 березня 1859 року, яким парк передається Головному училишу садівниџтва, переведеному з Одеси в Умань. 31923 року парк «Софіївка» став називатися садом III Інтернаціоналу. Під час п'ятого періоду (1929-1955) згідно з Постановою Раднаркому Української Соџіалістичної Радянської Республіки № 26/630 від 18 травня 1929 року парк оголошується заповідником, шо обмежило санітарні рубки та інші роботи. Шостий період (1955-1980) розпочався 26 вересня 1955 року коли Уманський державний заповідник «Софіївка» на підставі Постанови Ради Міністрів УРСР № 1184 передається в відання Академії наук УРСР і підпорядковується в своїй науковій діяльності Џентральному ботанічному саду АН УРСР, зберігаючи статус самостійної установи АН УРСР. Початок поточного сьомого періоду ми виділяемо з початку проведення найбільших реставрадійних, ремонтних та відновлювальних робіт у «Софіївці», шо проводилися після стихійного лиха, коли в ніч з 3 на 4 квітня 1980 року весняна повінь і селевий потік з величезними брилами льоду практично знишили основні малі архітектурні форми в історичній частині парку, його дорожньо-алейну систему, скульптури, рослинний покрив, пошкодили ряд вікових дерев тошо. Після џього зусиллями співробітників парку і за допомогою всієї уманської громади протягом чотирьох місяџів було реставровано понад п'ятдесят об’єктів, «Софіївка» знову 
набула колишнього блиску (Косенко, 2013; Kosenko et al., 2020). Нині вона не лише успішно розвивається у традиџійних напрямах, а й започаткувала нову соџіально-освітню програму для відвідувачів з особливими потребами (Kosenko et al., 2021).

Матеріали й методи. Ретроспективний огляд історії романтичного парку «Софіївка» - шедевра садовопаркового мистецтва 18-19 століть, його ботанічної колекџї̈, а також засновників і творџів його майбутнього, виконано внаслідок узагальнення ботанічної й історичної літератури та архівних матеріалів з використанням загальновживаних методів теоретичного аналізу, систематизаџї, порівняння й типізування (Hurrell et al., 2019).

Результати та обговорення. Для осмислення історії «Софіївки» варто коротко ознайомитися з історією Уманшини і життям її тодішнього суверена графа Станіслава Щенсного Потоџького (Stanisław Szczęsny Potocki). Уманщина, котра в ті роки входила до складу Речі Посполитої, була подарована польським королем Сигізмундом III Ваза, графу Валентину Олександру Калиновському, який передав її як посаг одній зі своїх дочок - Гелені. Вона в 1726 роџі продала маєток Станіславу Потоџькому, а він у 1732 роџі подарував його своєму небожу Франџішку Салезію Потоџькому (Kosenko et al., 2020).

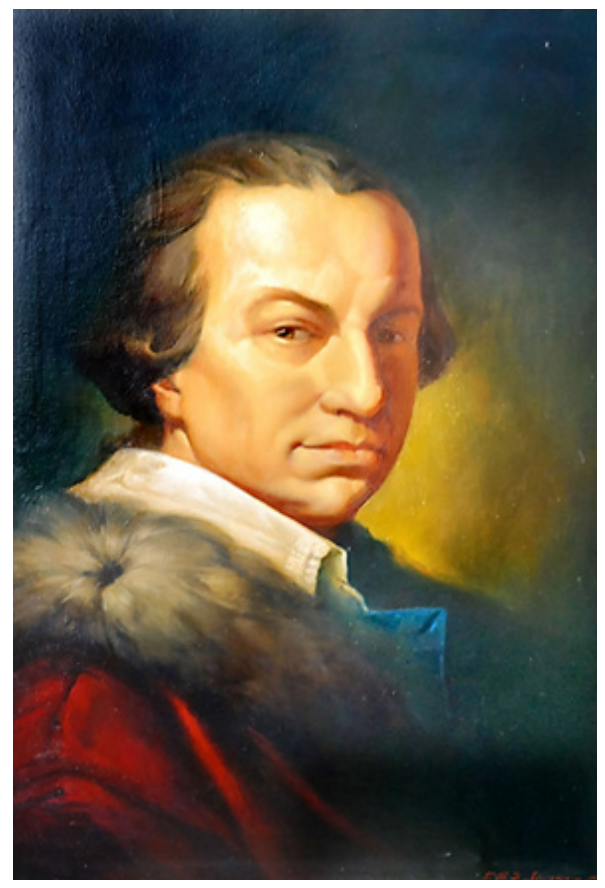

Рис. 1. Граф Станіслав Щенсний Потоџький

Магнат Франџишек Потоџький, онук коронного гетьмана Речі Посполитої, шо походив зі старовинного роду Малопольської шляхти, був дуже заможним паном (Dunin-Borkowski, 1908). Його резиденџія в м. Кристинопіль (нині м. Червоноград, Львівської області) за розкошію не поступалася резиденџї польського короля. Станіслав Џенсний (рис. 1), єдиний син Франџішка Салезія Потоџького і Анни Ельжбети народився у 1751 роџі (Wolszczanowa, 1972). Вихователем його був ксьондз Вольф, для свого часу дуже освічена людина. Він прагнув прищепити юному графу високу мораль, почуття милосердя й турботи про селян, які своєю праџею будуть примножувати його багатства. Батьки Щенсного були надзвичайно суворої вдачі, а мати - відверто деспотичною стосовно виховання сина і його долі. Батьки мріяли, що дружиною їхного сина стане якщо не королівська дочка, то щонайменше донька дуже заможного князя чи графа. Однак юний Станіслав покохав Гертруду, доньку графа Якуба Комаровського, котрий володів лише кількома селами. 3 нею Щенсний у 1770 роџі таємно від своїх батьків обвінчався. Џе заміжжя коштувало Гертруді, вже вагітної, життя. За наказом Салезія Потоџького Гертруду викрали, щоб заточити її до монастиря.

Дорогою, на одному з кордонів, шоб Гертруда часом не видала своїх викрадачів криками про допомогу, її щільно накрили кожухами, під якими нещасна й задихнулася. Труп Гертруди вкинули під лід в ополонку ставка. Дізнавшись про џе, юний Потоџький намагався накласти на себе руки, але його врятував слуга. Батько Гертруди розпочав судовий проџес, який загрожував Салезію Потоџькому баніџією - вигнанням з Польщі. Не в змозі пережити очікуваної ганьби, на початку 1772 року помирає мати Џенсного, Анна Ельжбета, а 11 жовтня того ж року і його батько (Kosenko et al., 2020).

Обтяжений мільйонними боргами батька, двадџятирічний Станіслав Шенсний Потоџький залишився єдиним господарем величезного маєтку. Молодий магнат не забажав жити в Кристинополі, котрий унаслідок першого поділу Польші у складі Галичини відійшов до Австрії. Тож після одруження в 1774 роџі на Юзефині Амалії Мнішек - багатій нареченій зі знатного графського роду, Станіслав Щенсний через рік переніс свою резиденџію на територію тодішньої Польші, в Тульчин. Усі свої галиџькі маєтки він передав графу Попінському, який зобов’ язався за џе сплатити борги батька та додатково передав Потоџькому на 50 років права на користування державним Звенигородським старостатом (Kosenko et al., 2020).

У 1774 роџі вперше відвідавши свої маєтки на Правобережній Україні Станіслав Џенсний був вражений красою џього краю й родючістю його земель. Ним опанувало бажання господарювати. Тож у 1782 роџі 
у Тульчині було споруджено чудовий палаџ; тут же був закладений великий парк, багатий не тільки місџевою,

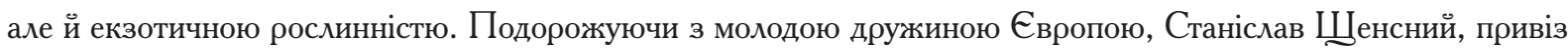
з Італії до Тульчина багато саджанџів пірамідальної тополі. У своїх маєтках він приділяв велику увагу вдосконаленню сільського господарства і множенню лісів. Головний керуючий маєтками був знаним фахівцем своєї справи. Окрім звичайних обов'язків він мав стежити, шоб усі селяни кожні шість років саджали у своєму дворі певну (визначену для кожного) кількість дерев яблуні, груші, вишні і шовковиџі. Зобов'язувалися також селяни на своєму подвір'ї, а також у ярах та різних непридатних для оранки землях висаджувати для своїх потреб швидкорослі дерева - верби й тополі. Навесні всі села у маєтках Станіслава вкривалися білим џвітом фруктових дерев (Łojek, 1995, 1998).

У жовтні 1791 році Станіслав Потоџький та гетьмани Северин Жевуський (Seweryn Rzewuski) і Ксаверій Браниџький (Franciszek Ksawery Branicki) прибули в Ясси на головну квартиру російських військ, які брали участь у війні з Туреччиною, для обговорення плану протидії новим законам польського сейму, шо ушемляли права шляхти. Џілком ймовірно, шо саме тут, в Яссах, відбулося знайомство Потоџького з прекрасною грекинею Софією (рис. 2), дружиною генерала російської армії, коменданта Херсона, графа Юзефа Вітта (Kosenko et al., 2020).

Хто ж вона, ця загадкова жінка, для якої незабаром був побудований один з краших парків світу і названо ï ім'ям? Співіснують дві версії походження Софії. Згідно з першою версією, опублікованою Боскампом-Лясопольским (Boscamp-Lasopolski, 1963), вона народилася 1 січня (11 січня за новим стилем) 1760 року (можливо 1761 або 1762) у туреџькому місті Бурса, що розташоване в 100 км від Стамбула в провінџії Бітинія, в сім'ї бідного скототорговџя грека Костянтина. У 70 -х роках родина Софії переїхала до Стамбула, де приблизно в 1775 роџі помирає іiї батько; потім іiї мати Марія виходить заміж за вірменина, котрий також незабаром вмирає. На додаток до џього подвійного лиха, під час великої пожежі в Стамбулі згорає іхній будинок. Опинившись без засобів до існування, Марія, за прикладом своєї молодшої сестри, колишньої дружини купџя Главані, стала стамбульської куртизанкою і звідниџею, яка промишляла в районі Пера, де були розташовані іноземні посольства. 10 чи 11 травня 1777 року обставини змусили Марію привести свою Дуду (так звали Софію в сім'ї) до польського посла в Туреччині Кароля БоскампаЛясопольского. Надзвичайна врода Софії справила на посла таке сильне враження, що він не лише поселив її у своєму палаці, а й найняв для неї вчителя франџузької мови. Подальша

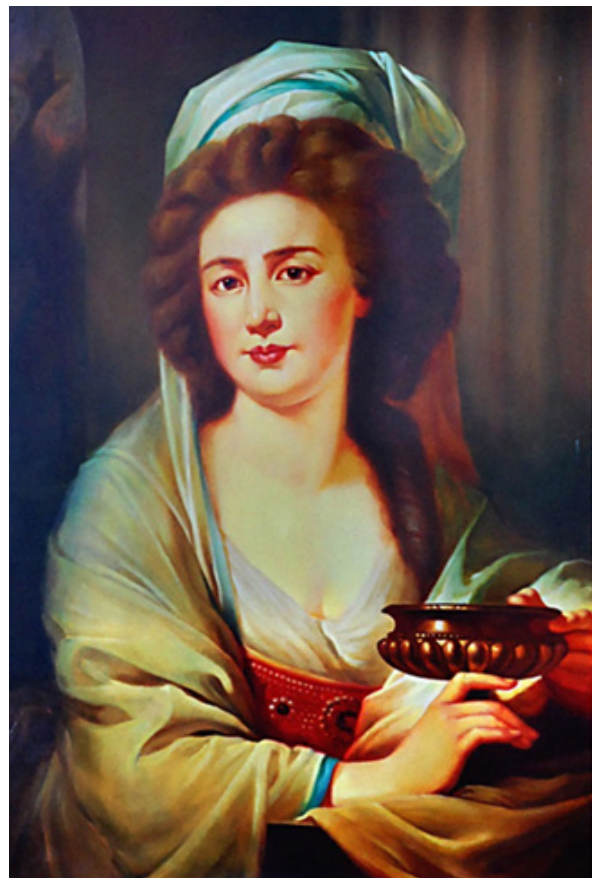

Рис. 2. Графиня Софія Главані (де Вітт) Потоџька історія Софії переповнена неймовірними романтичними приго-

дами під час її численних подорожей, які почалися після переїзду з Туреччини до Польщі (через Болгарію) і вельми вдалого заміжжя з сином коменданта Кам'янеџької фортеџі 39-річним майором Юзефом Віттом. Софія зуміла переконати Юзефа Вітта у другій (власній) версії свого походження зі знатного роду Панталіса Маврокордато, шо належав до родини греџького престолу, спорідненої трону Візантії, і $є$ донькою греџького магната Костянтина Челіче (Celice) й Марії Главані (Glavani), правнучки Панталіса (Ролле, 1887). Майор шалено закохався в прекрасну грекиню, і вже 14 червня 1779 року Софія і Юзеф таємно від його батьків обвінчалися.

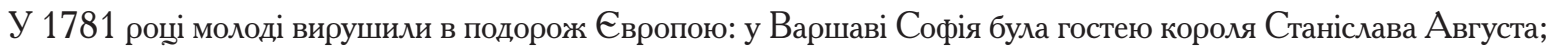
у Берліні познайомилася з королем Пруссії Срідріхом II; а у бельгійському курортному місті Спа - з австрій-

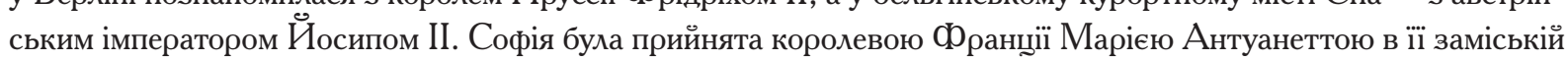
резиденџії, Малому Тріаноні, який саме тоді перебудовувався в пейзажний парк, i, можливо, тут вперше у Софії виникла ідея побудувати схожий парк, яку вона згодом і втілила на своїх землях в Україні. У Парижі на 
Софію звернули увагу граф Прованський, пізніше король Людовик XVIII і молодий граф д’Артуа, майбутній король Карл X (Kosenko et al., 2020).

У 1787 році Софія з групою польських магнатів відвідала Стамбул. Серед туристів була й дочка сестри короля, дружина коронного маршала, Урсула Мнішек. За непідтвердженими чутками взимку 1787/88 $\rho$. Софія відвідала Санкт-Петербург, де нібито зустрічалася з цариџею, а в травні 1788 року їздила з герџогом Шарлем-Жозефом де Лінем, шо перебував на військовій службі в Росії, під Хотин, обложений тоді російськими військами. Вона занадто багато часу проводила в російському таборі, шо викликало невдоволення поляків її чоловіком, комендантом Кам'янџя графом Юзефом де Вітт. У 1789 роџі Юзеф де Вітт прибув із Софією до Варшави і став домагатися дозволу на продаж своєї посади коменданта, однак отримавши відмову, він порвав стосунки з Польшею і перейшов на службу Росії.

Немає точних відомостей шодо того, коли Софія познайомилася з головнокомандувачем російської армії

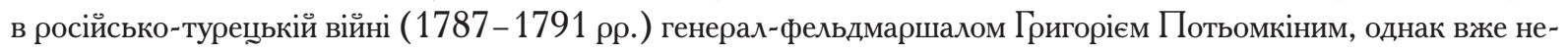
забаром вона опинилася під Яссами, а її чоловіка Юзефа де Вітта Потьомкін призначив комендантом Херсона з присвоєнням йому звання генерала російської армії. Повернувшись у Ясси, Софія зацікавилась Станіславом Шенсним Потоџьким. Антоній Юзеф Ролме стверджував, шо саме Софія, як агент Григорія Потьомкіна, схилила Станіслава Потоџького на боротьбу проти нової польської конституџії (Ролле, 1887). Закохавшись Станіслав Шенсний зовсім втратив голову і повністю опинився під владою любовних чар Софії. Про стосунки Станіслава Потоџького з Софією у Варшаві і в Санкт-Петербурзі ходили справжні легенди. Дійшли вони і до Юзефини Потоџької у Відень, але вона сама була не без гріха і поводилася з неменшою свободою.

Опісля Другого поділу Польщі Станіслав Потоџький вирішив назавжди полишити Польщу й Росію, де опинилися його володіння. 7 травня 1793 року він уклав договір зі своєю дружиною, за яким керівниџтво маєтками переходило Юзефини, а вона натомість зобов'язувалася надсилати йому шорічно 50 тис. дукатів (900 тис. польських злотих) у два прийоми. Потім він виїхав з Санкт-Петербурга морем до Гамбургу, де й оселився разом з Софією. У 1795 роџі відбувся Третій поділ Польші. Росія приєднала Литовшину, возз’єднала Західну Білорусь і Волинь після чого Річ Посполита припинила своє існування як незалежна держава. Однак Потоџький, як і більшість польських магнатів-феодалів, не втратив свої маєтки. У травні 1795 року Станіслав Шенсний Потоџький остаточно вирішив розлучитися з дружиною і повернутися в свої маєтки, а Софія

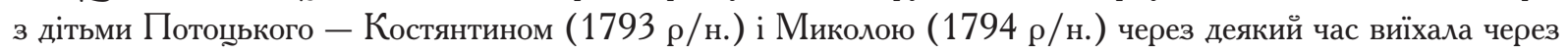
Познань і Варшаву до Львова, шоб розпочати справу про розлучення з де Віттом. Неподалік від Варшави Софія зупинилася в містечку Неборове у графині Гелени Радзівіл, де відвідала иї розкішний парк «Аркадія», побудований у романтичному стилі з елементами греџької міфології. Про свої враження Софія писала Потоџькому: «Після обіду поїхали подивитися Аркадію. Важко собі уявити шось краше й романтичніше. Ти знаєш Аркадію, однак бачив її 10 років тому. Уяви собі, як можуть вирости молоді дерева за 10 років і як багато тут зроблено для поліпшення џього місџя..., в Аркадію я закохана до безтями; немає в світі жодного виду квітів і екзотичних рослин, яких би тут не було. Гуляючи садами Аркадії, я відчувала, шо в розпал літа переживаю знову весну і кожне дерево ніби говорить: “Мені тут добре!” Аркадія дуже нагадує мені Крим; ти знаєш, що в тім краю при твоїх статках можна 6 мати протягом двох років таку ж саму, а може й більш прекрасну Аркадію, адже там не потрібні штучні насадження? Правда, мій милий друг, шо ми будемо мати сільџе в Криму? ... ». У наступному листі від 19 липня вона доповнила своє прохання побажанням: «... якщо будемо мати садибу в Криму, накажеш встановити там органи такі самі, як і у Радзівілів в Аркадії? ...». Однак Софія не знала дійсного стану фінансових справ Шенсного, а вони були настільки кепські, що він не міг братися за придбання маєтку в Криму. Дружина Потоџького Юзефина зі своїми керуючими довела маєток, мало не до повного краху. Потоџький у Санкт-Петербурзі згоди на розлучення не отримав, тому шо Юзефину підтримувала Катерина II. До початку осені 1795 року він прибув до Умані, оскільки до Тульчина час від часу навідувалася Юзефина, сподіваючись зберегти шлюб зі Щенсним. У лютому 1796 року Софія, вперше, приїхала в Умань. А невдовзі їі розлучення з де Віттом було остаточно оформлене (Kosenko et al., 2020).

Потоџькому ж розлучитися з дружиною вдалося лише після смерті Катерини II. Вінчання Шенсного з Софією відбулося 17 квітня 1798 року в Тульчині у православній џеркві, яка замінила уніатський костьол після другого поділу Речі Посполитої (1793), унаслідок якого Правобережна Україна увійшла до складу 
Російської імперії. В очікуванні прибуття Софії зі Львова до Умані, Потоџький взимку 1796 року часто полював в околиџях міста з талановитим польським артилерійським офіџером, капітаном Людвігом Метџелем (Ludwik Chrystian Metzell). Побували вони й в урочиші Кам'янки, що впадає в річку Уманка. Џе порізане ярами урочище було надзвичайно мальовничим. Тож одного разу Потодький розпочав розмову з Людвігом Метџелем про можливість влаштування тут парку, який він вирішив назвати на честь своєї майбутньої дружини Софії «Софіївка». Згодом і Софія џю місџевість визнала џілком придатною для парку. Вирішальне значення у виборі саме Людвіга Метџеля керівником будівниџтва нового парку відіграли його глибокі знання й талант (Косенко, 2010).

За свідченням Теодора Темері (Themery, 1846) спочатку Станіслав Потоџький планував перетворити всю долину річки Кам'янки з мальовничими пагорбами й гранітними скелями у величезний ангдійський парк, прикрашений численними каскадами і фонтанами, гідними краших садів сходу. Навколишні пагорби планувалося

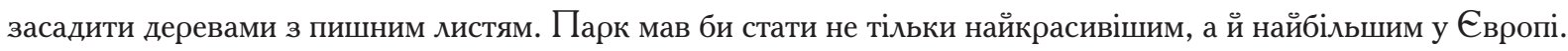

У 1796 роџі Людвиг Метџель отримав завдання розпочати будівниџтво. 3 џього бере відлік історія парку, який невдовзі був названий «Софіївка». У помічники Людвігу Метџелю був «виписаний краший з чужих країв садівник». Хоча в листуванні Метцеля з Комаровським не вказано ім'я садівника, однак є інформаџія, що џе був німеџький садівник Олива (Храбан, 1971).

Будівельні роботи розпочалися у майже безлісій місцевості, розділеній річкою Кам'янкою, а також балками та ярами, про шо читаємо у написаній у 1815 роџі Станіславом Трембеџьким поемі про «Софіївку» (Trembecki, 1815). На території, де створювався парк, тоді були тільки дві старі груші та з десяток верб. Однак у західній частині парку донині росте дуб, вік якого досягає близько 400 років. У підліску насаджень парку до сьогодні широко представлені типові дібровні трав'янисті рослини. Слід гадати, џо в џій частині парку раніше була діброва, яка мабуть була вирубана місџевими жителями ще до початку будівниџтва «Софіївки» як найближчий до міста лісовий масив (Kosenko et al., 2020).

Одночасно з будівельними роботами висаджувалися не лише місцеві, а й екзотичні рослини, про що свідчать листи, які Людвиг Метџель писав Потоџькому. Так 27 листопада 1799 року він попросив Потоџького доставити з Тульчина побільше дерези звичайної (Lycium barbarum L.), якої майже не було в «Софіївці». Џей чагарник планували висадити біля греблі Верхнього ставка і в інших місџях; Метџель також просив дозволу привезти з Дашевського саду (нині Гайсинський район, Вінниџької області) саджанџі верби плакучої (Salix babylonica L.) для садіння на березі острова Анти-Цирџеї, розташованого на Верхньому ставку (рис. 3).

Він доповів графу, шо весною 1799 року в парку було закінчено висаджування місџевих порід дерев. Можна вважати, шо основа паркових насаджень була в 1796-1812 роках закладена переважно деревними породами лісового типу місџевого походження. Екзотичні рослини висаджувалися здебільшого в захищених
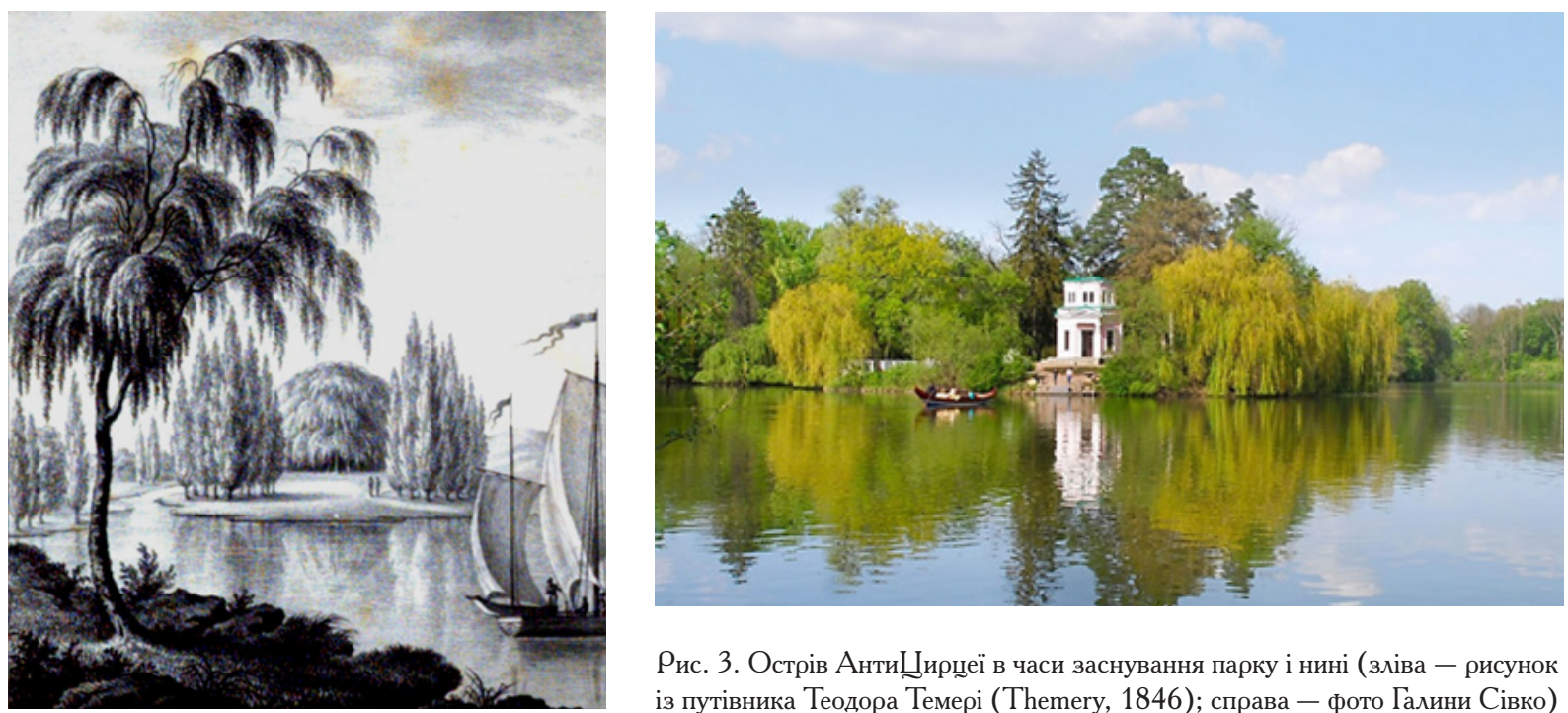

Рис. 3. Острів АнтиЏирџеї в часи заснування парку і нині (зліва - рисунок із путівника Теодора Темері (Themery, 1846); справа - фото Галини Сівко) 
від північних вітрів місцях џентральної частини парку: у Темпейскій долині, на Єлисейських полях і поряд з гротом Сетіди (Trembecki, 1815).

Рідкісні екзотичні рослини завозили до Умані (через Одесу) з Азії, а також з Італії та Криму. У поемі Трембецького (Trembecki, 1815) згадується про те, шо поряд з відомими всім нам деревами в парку були висаджені «гості» з Ісландських Антиподів, Гі Атласу та Лівану. У першому путівнику по парку, виданому у Вільно в 1843 роџі Сільвестром Грозою (Sylwester Wezyk Groza), названі: верба, ялина, груша, береза, тополя, липа, ряд плодових дерев і троянди. Повідомляється також про багатство кольорів, џо прикрашали окремі ділянки і висаджені в вази олеандри, гібіскуси китайські, гвоздики та інші незвичні для тих часів рослини (Groza, 1843).

14 березня 1805 року магнат раптово помер. Однак, хоча первісний план грандіозного будівниџтва «Софіївки» вже ніким не був здійснений, те, шо було створено кріпаками Уманшини під керівниџтвом талановитого зодчого Людвіга Метџеля і його помічника Оливи, отримало відразу загальне визнання як шедевр садовопаркового мистеџтва. За твердженням Грози, роботи шодо вдосконалення «Софіївки» не припинялися до від'їзду Людвіга Метџеля до Варшави. «Шодня, - пише він, 一 майже декілька десятків людей були зайняті вибуховими роботами й шліфуванням граніту, висаджуванням дерев і вдосконаленням водної системи». Софія Потоџька «не шкодувала коштів для примноження краси «Софї̈вки»... Безліч величезних скель, долини і пагорби ..., все џе було 6 напівмертвим, якби не смак і не майстерність Людвіга Метџеля ... Велика завжди природа, але якою вона стає великою в руках досвідченого майстра» (Groza, 1843).

У 1813 роџі Людвіг Метџель був призначений начальником управління сухопутних і водних шляхів сполучення Польського королівства і виїхв з Умані до Варшави. Після смерті Станіслава Шенсного Потоџького управління маєтком перейшло до рук його старшого сина Юзефа, картяра і марнотратника. У Санкт-Петербурзі він оформив передачу своїй мачусі, Софії Потоџькій, права розпоряджатися тією частиною маєтку, яка припадала на її частку спадшини і частку її дітей, до якої увійшла й «Софіївка». Парк у ті часи утримувався у взірџевому стані. У 1820 роџі «Софіївку» відвідав російський імператор Олександр I. Навесні наступного року Софія надіслала до Санкт-Петербурга транспорт із саджанџями пірамідальної тополі. 30 червня 1821 року імператор власноруч написав Софії Потоџькій листа, в якому висловив їй џиру подяку за џей дарунок. Однак самій Софії через невиліковну хворобу залишалось вже жити недовго. Восени 1821 року вона вирушила до Санкт-Петербурга, де 22 травня 1822 року оформила свій заповіт. Не повертаючись до Умані, Софія просто зі столиџі виіххала до Берліна, де й померла 12 (24) листопада 1822 року (Kosenko et al., 2020).

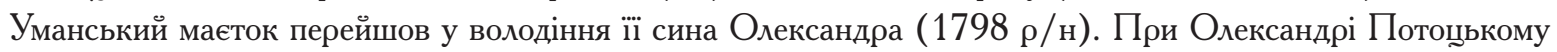
в парку були встановлені біломармурові статуї: бюст Тадеуша Костюшка - Наџіонального героя Польші, Литви, Білорусі й США, а на о. Ітака - скульптуру наполеонівського генерала Юзефа Понятовського, небожа останнього польського короля Станіслава Августа Понятовського. Антоній Анджеєвський на прохання Олександра Потоџького склав опис рослинності парку. Відвідувачі парку зазначали, шо за нього «Софіївка» зберігала колишній блиск. Софія Кисельова, старша сестра Олександра Потоџького підтримала Листопадове повстання (1830-1831 рр.) у џентрі розділеної Польщі проти Російської імперії, хоча і була одружена з царським фаворитом графом Павлом Кисельовим. Повстання було придушене протягом року. Однак Олександр Потоџький під впливом Софії Кисельової прибув до Варшави напередодні розгрому повстання і надав гроші на формування полку. Після взяття в жовтні 1831 року џарськими військами Варшави імператору стало відомо, шо Олександр Потоџький приєднався до повстання поляків. Тому було видано џарський указ, на підставі якого всі маєтки «заколотника» Олександра Потодького були секвестовані, проте до березня 1832 року уманським маєтком ше продовжував керувати уповноважений Олександра. У 1832 роџі парк, як і вся власність Потоџьких, був конфіскований і переданий Київській державній палаті, яка призначила управителем уманським маєтком гвардії капітана Маркевича. Розуміючи цінність «Софіївки» як шедевра садово-паркового мистеџтва і усвідомлюючи, шо для збереження парку необхідний постійний догляд за рослинами імператор Микола I вирішив подарувати парк свої̈ дружині Олександрі Федорівні і повелів називати його Џариџиним Садом (Величенко, 2006).

Саме в џей період у парку з'явилися малі архітектурні форми та ландшафтні композиџії, створені за Осіанічними мотивами. Зокрема група гранітних брил на лівому березі річки Кам'янка, біля яких росте таксодій 
(Taxodium distichum (L.) Rich.), представник родини Кипарисових (Cupressaceae Gray, nom. Cons.), котрий дає џілком оссіанічні відчуття як і фонтан «Змія» чи Тарпейська скеля з альтанкою на їі вершині (Косенко, 2008; Василевич, 2009).

Відповідно до указу імператора Олександра II у березні 1859 року парк отримав нову офіџійну назву «Уманський сад Головного училиџа садівниџтва», проте назва Џариџин Сад неофіџійно вживалася аж до встановлення комуністичного режиму в Україні. Головні насадження у џей період були зроблені під керівництвом і за безпосередньої участі професора Василя Пашкевича, викладача Головного училища садівниџтва, який заснував на території парку збережений донині і розвинений Англійський парк (Косенко, 2013), відомий як арборетум Пашкевича.

Більш докладні відомості про рослинний світ «Софї̈ки» кінџя 19 сторіччя знаходимо в путівнику по парку складеному Теодором Темері (Themery, 1846). Описуючи «Софіївку» він знову повідомляє про вже згадані дві старі груші й десяток верб, які збереглися з часів, шо передували будівниџтву парку, а також про чудові берези, масиви великих тополь, в'язів і численні насадження місџевих лісових дерев, зроблені Людвигом Метџелем на підвишених місџях. Розповідаючи про оранжереї «Софіївки», шо були збудовані ше за Станіслава Потоџького, Темері описує чудовий партер з різнокольоровими квітами, розбитий вздовж теплиџь. 3-поміж оранжерейних рослин названі пальми, вкриті плодами фігові дерева (інжир), запашні ананаси. Џікаво й те, шо велика частина оранжерейних рослин у літній період використовувалася для прикрашання парку. Південні рослини майстерно розставлялися по всьому саду (Косенко, 2013).

Так, наприклад, біля сходів до партерного амфітеатру розміџувався апельсиновий масив, на березі потічка красувалися сосна австралійська (Casuarina equisetifolia L.) та південна магнолія (Magnolia grandiflora L.) й інші екзотичні для України рослини. До періоду заснування також належать висаджені у парку платан (Platanus occidentalis L.), гледічія (Gleditsia triacanthos L.), сосна Веймутова (Pinus strobus L.), глід (Crataegus spp.), каштан кінський (Aesculus hippocastanum L.), ясен плакучий (Fraxinus excelsior L. 'Pendula'), туя східна (Thuja occidentalis L.), сосна (Picea spp.), робінія псевдоакаџія (Robinia pseudoacacia L.), жарновеџь віниковий (Cytisus scoparius (L.) Link), та карагана (Caragana arborescens Lam.). У џей період також було посаджене

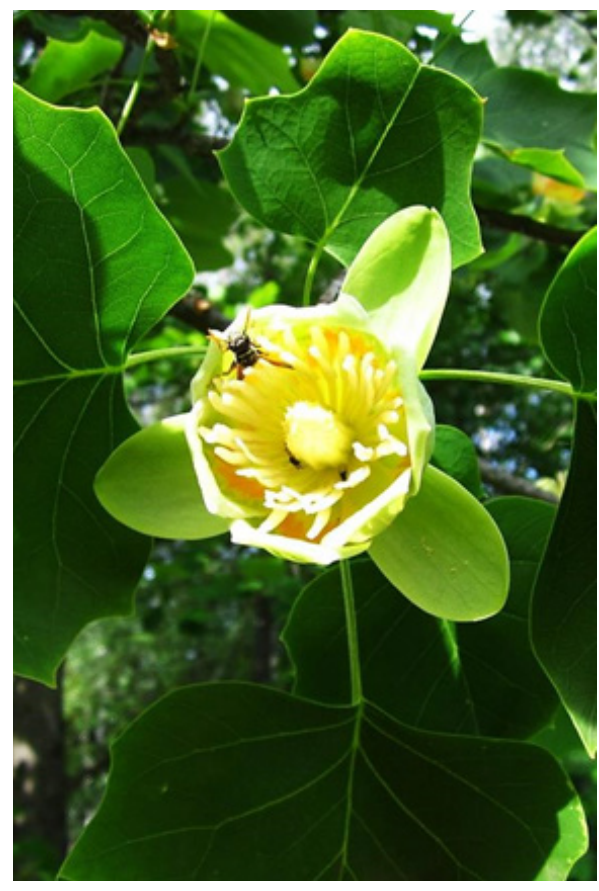

Рис. 4. Квітка Liriodendron tulipifera тюльпанове дерево (Liriodendron tulipifera L.), однак те дерево, дивовижні квіти якого радують око сьогодні (рис. 4), це рослина, отримана внаслідок розмноження порослю колишнього дерева (Білик та ін., 2000; Косенко, 2013).

Все џе дає підстави стверджувати, що «Софіївка» з самого початку була побудована на принџипах штучних біоџенозів, які включали квітникові, газонні, деревні і чагарникові композиџії, скомпоновані так, шоб тішити око видами прекрасних близьких і далеких перспектив, створюючи при џьому відчуття натуральності й наближеності до природи (Kosenko et al., 2020).

Згідно з Постановою Раднаркому УРСР № 26/630 від 18 травня 1929 року парк «Софіївка» оголошується заповідником. Оранжерея, парники і, відповідно, частина території парку залишаються у віданні нинішнього Уманського наџіонального університету садівниџтва (колишня Головна школа садівниџтва). Парк отримує самостійнй статус, і до 1955 року перепідпорядковується декілька разів різним відомствам. Зокрема відразу після Другої світової війни у 1945 роџі парк (без зміни статусу) отримує нову повну назву: «Уманський державний заповідник «Софіївка», а у 1948 роџі затверджується генеральний план його відновлення й розвитку, у рамках якого у наступному (1949) роџі створюється декоративний розсадник плошею 20 га. Активно проводяться роботи з ремонту і реставраџії малих архітектурних форм, дорожньо-алельної системи, 
скульптур парку. Проводиться інвентаризаџія деревних і чагарникових порід, видаються наукові праџі з історії парку, його дендрофлори, публікаџї̈ про його скульптури, малі архітектурні форми тоџо (Косенко, 2013).

Џілеспрямований розвиток парку як ботанічної установи розпочався з 26 вересня 1955 року, коли заповідник «Софї̈вка Постановою Ради Міністрів УРСР за № 1184 був переданий у відання Академії наук УРСР і став підпорядковуватися в своїи науковій діяльності Џентральному ботанічному саду АН УРСР, зберігаючи статус самостійної установи АН УРСР. У џей період проводяться значні роботи з реставраџії об'єктів парку і їхнього відновлення, розширення території парку, створення нових і поповнення існуючих колекџій рослин. Протягом 1980 - 1993 років на території розсадника побудовані: теплиџя плошею 0,4 га, підвал для зберігання саджанџів площею 180 м2 з надбудованим над ним півтора-поверховим примішенням, в якому забезпечено всі послуги та побутові кімнати для праџівників даного підрозділу; для вкорінення кореневласних саджанџів у теплиџі встановлена система створення дрібнодисперсного туману, контейнерний майданчик; збудована водонапірна вежа з власною свердловиною і водонапірна станџія, звідки подається вода для поливу (Косенко, 2010; Kosenko et al., 2020).

За проведену в џі роки роботу адміністраџія «Софіївки» в 1995 роџі була нагороджена медаллю, дипломом і пам' ятним знаком всеєвропейської федераџї культурної спадщини “Europa Nostra” за краще збереження, відновлення і реставраџію пам' яток історії, культури, архітектурних споруд і природних ландшафтів (Кosenko et al., 2020).

На виконання розпорядження Президента України № 26/93рп від 10 березня 1993 року і Постанови Кабінету Міністрів № 456 від 16 червня 1993 року «Про заходи шодо підготовки та відзначення 200 років заснування дендрологічного парку «Софіївка» Академії наук» Київським інститутом «УкрНДІінжпроект» був розроблений проект Генерального плану благоустрою, відновлення і розширення парку (Косенко, 2010).

Всі нововведення виконувались за Генеральним планом відповідно до вимог Фрлорентійської хартії з метою збереження історичної частини парку. Натомість за межами історичного ядра, були створені відповідні умови для поглибленої наукової роботи з інтродукованими деревними та чагарниковими рослинами, що за правилами Флорентійської хартії не дозволяється робити в історичній, експозиџійній, зоні парку. Тут же, безпосередньо перед новим входом з вул. Київська, був збудований науково-лабораторний корпус корисною площею 3308,2 м², в якому наукові співробітники парку розробляють нові технологї збереження унікальності «Софіївки», як і інших парків держави, для наступних поколінь. У џентральній частині корпусу на третьому поверсі створено музей «Софіївки», на другому - конференџ-залу на 200 учасників, на першому - вестибюль, у якому розмішені адміністраџія готелю і бар. Через головний вхід до џього корпусу можна потрапити і у його адміністративно-наукову частину, і до готелю. У підвальній частині будівлі обладнана сучасна лабораторія мікроклонального розмноження рослин і гербарна, а також насіннєва лабораторія (Косенко, 2010).

Саме в џі роки були досліджені архіви з історї̈ парку, внаслідок аналізу матеріалів яких відновлено історичні назви об'єктів парку, з' ясовано й деталізовано первинні сюжетні задуми паркових композиџій і розкрито їхню семантику, видано ряд монографій, наукових статей, зроблено багато доповідей на міжнародних і наџіональних конгресах і конференџіях, а завдяки постійним науковим експедиџіям не лише у найвіддаленіші куточки України, а також до ряду держав Європи й Азії, в колекџіях «Софї̈вки» значно зросла кількість рослин, завезених з-за кордону. Окрім того, робота з архівними документами засвідчила велику заџікавленість «Софіївкою» перших осіб держави, починаючи з перших років її існування. Так російський імператор Микола I відвідував уманський парк у 1828, 1830, 1837 та 1847 роках. Й ого захоплення парком було матеріалізоване в уже згадуваному указі 1836 року про дарування конфіскованої у Потоџьких «Софіївки» своїй дружині, Олександрі Федорівні, з перейменуванням парку у «ариџин Сад». 24 вересня 1859 року, невдовзі після підпорядкування парку переведеному з Одеси Головному училищу садівниџтва як навчально-дослідної бази для студентів џього елітного училища, відвідав «Софіївку» Олександр II. А у 20 -му сторіччі відвідини керівників нашої й іноземних держав, іноземних послів, відомих вчених та віп-персон набули масового характеру.

Багаторічна напружена робота колективу «Софіївки» була заслужено відзначена Указом Президента України № 249 від 28.02.2004 року, за яким дендрологічний парк «Софіївка» отримав статус наџіонального закладу з назвою - Наџіональний дендрологічний парк «Софіївка» НАН України. Підставою для џього історичного для «Софіївки» указу було її визнання на загальнодержавному рівні як пам' ятки садово-паркового мистеџтва 
світового значення та провідного науково-дослідного, природоохоронного і культурного џентру, котриї досягнув найвищих показників у свої діяльності шодо залучення інтелектуального потенџіалу наџї для реалізаџї програм науіонального відродження й розвитку України. Досягнуто загальнодержавне і міжнародне визнання результатів діяльності колективу парку, в якому праџюють відомі на світовому рівні фахівџі з величезним досвідом роботи, мають важливі наукові успіхи і реальні перспективи подальшого розвитку.

Черговим визнанням наукових заслуг колективу Наџіонального дендрологічного парку «Софіївка» НАН України стала постанова Президії НАН України № 68 від 6 квітня 2005 року, якою Наџіональному дендрологічному парку «Софї̈вка» надано статус науково-дослідного інституту НАН України і тепер його повна назва - Наџіональний дендрологічний парк «Софіївка» - науково-дослідний інститут НАН України.

26 вересня 2006 року на відзначення 210-річчя заснування «Софіївки» учасниками міжнародної наукової конференџії, присвяченої џій даті, було урочисто відкрито меморіальну зону рослинних композиџій, посаджених відомими людьми України й світу. У џеремонії відкриття та висадження першої рослини - дуба (Quercus robur L.) взяли участь 165 науковџів, у складі яких було ряд відомих вчених України і Європи.

У липні 2007 року на першому публічному конкурсі «Сім чудес України» з-поміж 100 претендентів унаслідок узагальнення результатів інтернет-голосування та опитування 100 експертів перші два місџя поділили «Софіївка» та Києво-Печерська лавра.

Комплексний опис складу колекџій рослин «Софіївки» було вперше виконано її науковими співробітниками ше напередодні 200-річчя заснування парку і узагальнено в Каталозі рослин дендрологічного парку «Софіївка». У каталозі були перераховані види, форми і сорти рослин із зазначенням місџя походження рослинного матеріалу, дати і місџя висаджування й кількості рослин кожного виду, дана характеристика життєвих форм, етапів онтогенезу, екологічних особливостей і перспектив практичного використання. 3 часу святкування 200 -річчя заснування «Софіївки» минуло вже 25 непростих для держави й парку років постійних творчих пошуків та напруженої роботи колективу «Софіївки» џодо збереження, вдосконалення та розширення парку, зміџнення його матеріальної і наукової бази. Завдяки џьому колекџї рослин НДП «Софіївка» нині нараховують близько 4000 таксонів живих рослин, з них майже 1000 деревних, більше 1500 кушових, понад 110 лісових та більше 1200 трав' янистих і водних рослин.

Нині в парку та в спеџіальних колекџіях «Софіївки» ростуть хвоџі (представники Equisetopsida C. Agardh); кілька папоротей (Polypodiophyta Cronquist, Takht. \& W. Zimm); доволі багато хвойних порід та інших голонасінних (Pinophyta Cronquist, Takht. \& Zimmerm. ex Reveal). Найбільше в колекџї «Софіївки» нараховується квіткових рослин (Angiospermae Lindl. або Magnoliophyta Cronquist, Takht. \& W. Zimm.).

Останніми десятиріччями суттєво поповнились колекџії: Anacardiaceae R. Br., Betulaceae Gray, Cupressaceae Gray, Ebenaceae Gürke, nom. cons., Fabaceae Lindl., nom. cons. (=Leguminosae Juss., nom. cons.), Ginkgoaceae Engl., Juglandaceae DC.ex Perleb, Iridaceae Juss., Magnoliaceae Juss., Moraceae Gaudich., Pinaceae Spreng. ex F. Rudolphi, Platanaceae T. Lestib., Rhamnaceae Juss., Rosaceae Juss. та інших родин.

$\mathrm{Y}$ результаті поповнення генетичної колекџї ліщини, що нараховує нині 33 таксономічні одиниџі - видів, різновидів, форм та сортів роду Corylus L. родини Betulaceae, з-поміж яких $11-$ у ранзі загальновизнаних видів, та близько 150 сортозразків (96 сортів вітчизняної й зарубіжної селекџії та понад 40 селекџійних номерів-носіїв господарче-џінних ознак) помологічної колекџії. Використання џієї генетичної колекџії фундука сприяло створенню ряду нових сортів фундука (Kosenko et al., 2019 a, b), зокрема занесених у 2019 роџі до Державного реєстру сортів рослин, придатних для поширення в Україні, високопродуктивних сортів 'Софіївський 1', 'Софіївський 2' та 'Софіївський 15' (Лішина велика..., 2021), створених внаслідок добору з гібридних популяџій, отриманих від запилення відомих сортів фундука ('Україна-50’, 'Дар Павленка' та 'Garibaldi') пилком лішини китайської (C. chinensis Franch.). Переваги 'Софіївського 15' стосуються форми ядра, шо відповідає вимогам технологічності для кондитерської промисловості, та відсутності в ньому порожнини, яка спостерігається у деяких інших сортів фундука (рис. 5).

Останніми десятиріччями почалося плідне співробітниџтво вчених «Софіївки» та експериментального закладу «Новокаховське» Інституту рису НААН України (Херсонська область) шодо підвишення зимостійкості хурми. Рід Diospyros L. хурма належить до родини Ебенові Ebenaceae Gürke. В Україні хурма вважається нетрадиџійною плодовою культурою, для адаптаџії котрої у степовій и лісостеповій зонах України насамперед необхідно 
підвиџити зимостійкість та ранньостиглість її нових сортів (Дерев'янко та ін., 2018).

Дані шодо перезимівлі хурми в екстремальні зимові сезони 2005/06 та

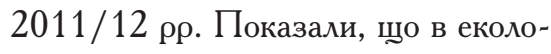
гічних умовах України сорти та форми, шо походили від хурми віргінської були більш морозостійкими, ніж у потомства хурми східної (Diospyros kaki Thunb) чи хурми кавказької (Diospyros lotus $\mathrm{L}$.).

Завдяки спешіальній програмі селекції на зимостійкість, яка включала гібридизадію хурми східної (Diospyros kaki) та хурми віргінської (Diospyros virginiana), що виконувалась на території експериментального закладу «Новокаховське» (з м'якшими зимами, аніж в Умані), та наступне пророшування in vitro недорозвиненого насіння міжвидових гібридів й
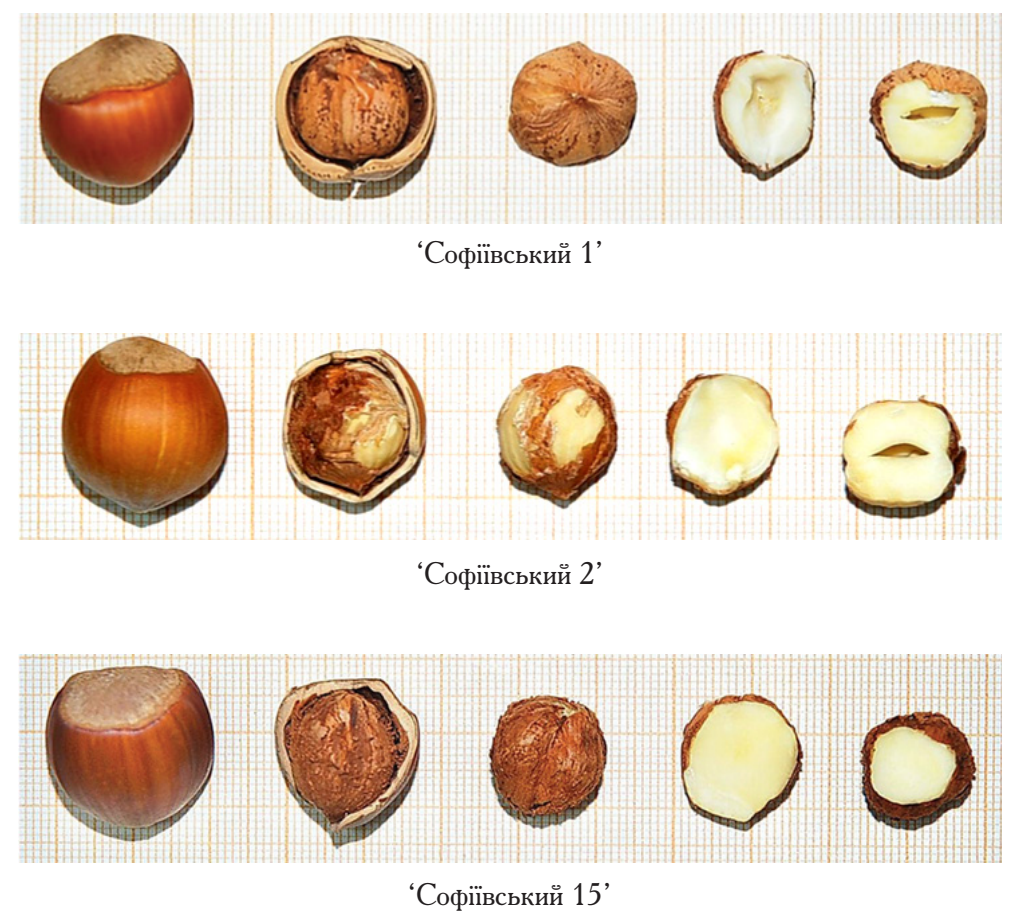

Рис. 5. Плоди сортів фундука селекџї̈ вчених «Софіївки» дороџування сіянџів у лабораторії

«Софіївки», гібридні сіянџі були адаптовані до умов ex vitro та були доведені до ринкових стандартів (Дерев'янко та ін., 2018). 3 популяџії таких гібридних сіянџів було відібрано ряд рослин, що дали початок ряду нових сортів хурми, зокрема сорту 'Дар Софї̈вки' (рис. 6), занесеному у 2019 році до Державного реєстру сортів рослин, придатних для поширення в Україні (Дерев'янко та ін., 2020; Хурма східна..., 2021).

Починаючи з 1999 року, проводиться цілеспрямована робота всього колективу парку з повернення «Софіївці» ного вигляду, коли вона славилася своїми газонами і квітниками, а також штучно створеними рослинними композиџіями в різних ландшафтних районах парку.

При џьому зберігається видовий склад, пошкоджені рослини замінюються молодими рослинами однойменних видів, саджанџі яких вирошуються в декоративно-плодовому розсаднику «Софіївки», шо розташований на ізольованій від парку території.

На території парку ше в 1910 роџі були висаджені декілька дерев плакучої шовковиџі (Morus alba 'Pendula'). Нині рослини џієї декоративної форми, шо належить до родини тутових (Moraceae Gaudich.) успішно розмножуються і періодично висаджуються в парку (рис. 7).

Територія парку розташована в зоні помірного клімату, де домінують листопадні види деревних рослин, які в пізньо-осінній та зимовий періоди залишаються без листя. Тому в парках таких регіонів особливо џінуються вічнозелені рослини і в солітерах, і як фон у ландшафтних композиџіях.

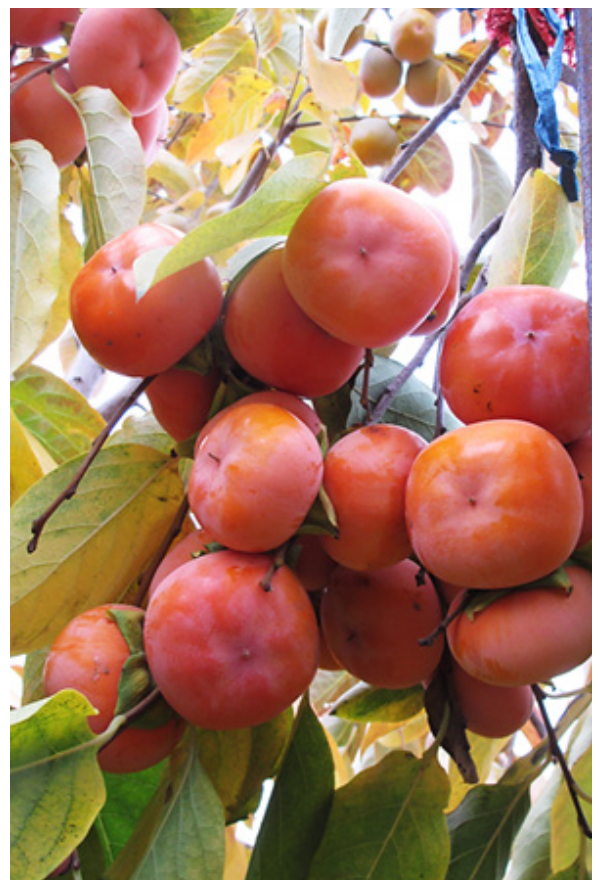

Рис. 6. Плоди нового сорту хурми (Diospyros spp.) 'Дар Софіївки' (плоди масою 130-150 грамів) 


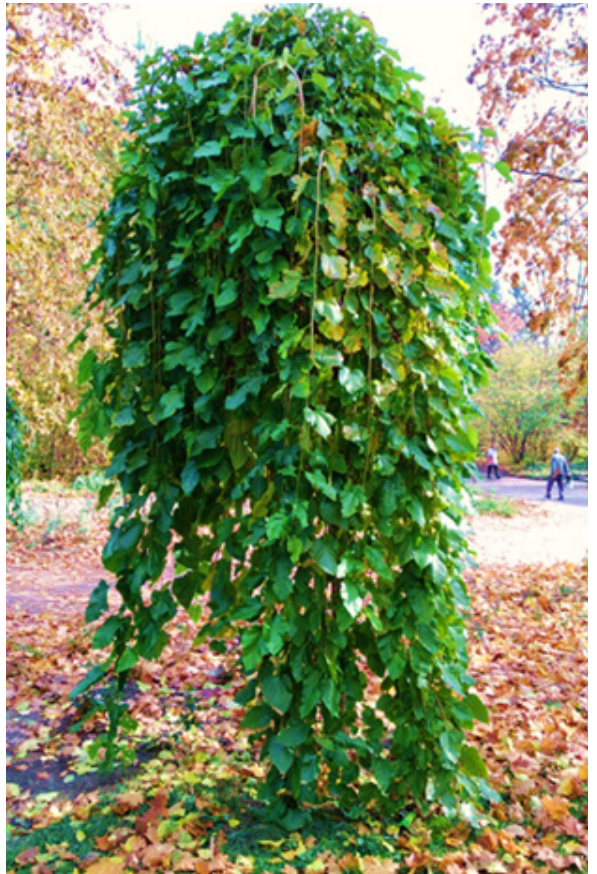

Рис. 7. Молоде дерево шовковиџі плакучої (Morus alba 'Pendula')
Родина Кипарисових (Cupressaceae Gray) представлена в «Сoфіївці» трьома видами та 8 сортами кипарисовика (Chamaecyparis Spach); 10 видами та 48 сортами ялівџю (Juniperus L.) й лише одним видом мікробіоти (Microbiota decussata Kom.); одним видом і сортом біоти (Platycladus orientalis (L.) Franco 'Glauca'); двома сортами туйовика (Thujopsis dolabrata (L. f.) Siebold \& Zucc.); двома видами та 16 сортами туї (Thuja L).

На фоні туї східної (Thuja occidentalis L.) і ялівџю горизонтального (Juniperus horisontalis Moench. 'Glauca') дуже привабливий вигляд має барбарис (Berberis vulgaris 'Atropurpurea') з темночервоно-фіолетовими чашолистиками з родини Berberidaceae Juss. (рис. 8).

Більшість тисових (Taхасеае S. F. Gray) посаджені в “Софіївџі” у другій половині 20 сторіччя. Џе тис ягідний и його внутрівидові таксони: Taxus baccata L., Taxus baccata 'Fastigiata', Taxus baccata 'Aurea' Taxus baccata 'Repandens' and Taxus cuspidata Siebold et Zucc. ex Endl.

Відвідувачам «Софіївки» дуже подобається вічнозелене маленьке дерево Taxus baccata з дуже декоративними червоними, ліхтариками шишкоягід (рис. 9).

У новій частині «Софіївки», розташованій за межами історичного ядра парку зовсім недавно створений новий, єдиний у Східній

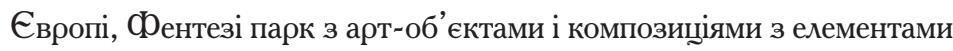

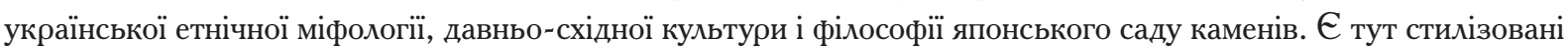
озера і водоспад “Дракони”, а вечорами з настанням темряви включаються світломузичні арт-інсталядії.

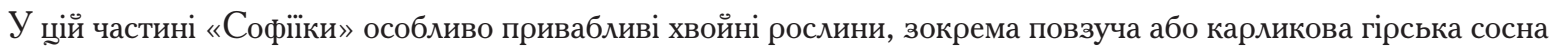
(Pinus mugo Turra), що належить до родини соснових (Pinaceae Lindl.) і представлена в парку як невелике деревце (Рис. 10).

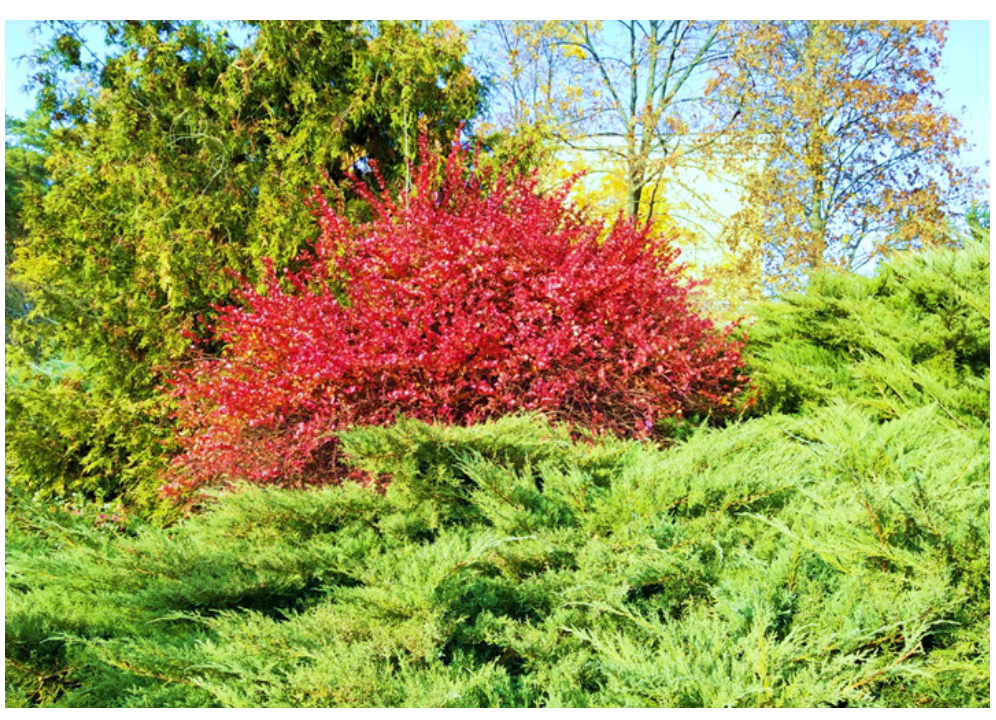

Рис. 8. Куш барбарису (Berberis vulgaris 'Atropurpurea') на фоні туї східної (Thuja occidentalis L.) і ялівџю горизонтального (Juniperus horisontalis Moench. 'Glauca')
А нешодавно, 7 серпня нинішнього року в џій новій частині «Софіївки», відкрився найбільший в Україні парк динозаврів - «DinoSofia». Џей безпечний для відвідувачів варіант відомого пригодниџького, фантастичного трилера «Парк Юрського періоду», доповнений майже живими динозаврами тріасового й крейдяного періодів Мезозойської ери, не залишить байдужим ні дошкільника, ані сивочолого ветерана.

Висновки. Минають роки, десятиліття, сторіччя, змінюються життеві пріоритети окремих особистостей, суспільних станів, џілих націй і народів, у багато разів швидше змінюються правителі великих держав, назви й кордони самих держав, змінюється підданство і прізвища власників «Софіївки» - вічна тільки любов в усіх її 
різноманітних проявах, яка надихає на великі творіння людського генія як втілення великого романтичного кохання.

Створена в «Софіївџі» сучасна матеріально-технічної база для виконання наукових досліджень, що стосуються моніторингу стану і збереження рослинного світу лісостепової зони України; підтримки і розвитку ботанічних колекџій, а також біотехнології, генетики, селекџї та репродуктивної біологї рослин; садово-паркового та ландшафтного будівниџтва не тільки забезпечує збереження історичного ядра і розвиток парку, а й сприяє створенню вже названих та інших нових сортів.

\section{入ітература}

Білик, О. В., Вегера, Л. В., Джим, М. М., Козлов, В. Г., Колдар, А. А., Косенко, І. С., Марно, А. І. ... \& Собченко, В. Ф. (2000). Каталог рослин дендрологічного парку «Софївка»: Довідковий посібник. [Ред.: І. С. Косенко]. Умань: Дендрологічний парк «Софіївка» НАН України. 160 с.

Василевич, Е. В. (2009). Хтоническая тема в оссианических парках. Известия Российского государственного педагогического университета им. А.И. Герцена. № 118. С. 242-246.

Величенко, М. Н. (2006). Подарок императриџе. Утраченные памятники «Софиевки». Плантомания. Российский вариант: Материалы XII Џарскосельской научной конференџии (2729 ноября 2006 г.). СПб.: ГМЗ «Царское село». С. 43-60.

Косенко, I. С. (2008). Осіанічні мотиви в паркових ландшафтах «Софіївки». Вісник Білоџерківського державного аграрного університету. Вип. 54. С. 19-23.

Косенко, І. С. (2010). Національний дендрологічний парк «Соіївка». К.: Академперіодика. 196 с.

Косенко, I. С. (2013). Ретроспективний огляд історії заснування, будівниџтва та утримання «Софіївки». Автохтонні та інтродуковані рослини. Вип. 9. С. 23-27.

Ліщина велика (фундук). Corylus maxima Mill.: Hazelnut. (2021). Державний реєстр сортів рослин, придатних для поширення в Україні на 2021 рік. Київ: Мінагрополітики. С. 464-465.

Ролле, И. (1887). Судьба красавиџы. Киевская старина. Том. 17. № 1. С. 99-138.

Храбан, Г. Ю. (1971). Перший архітектор «Софіївки». Український історичний журнал. № 9. С. 103-108.

Хурма східна (Diospyros kaki L.): Persimmon. (2021). Державний реєсто сортів рослин, придатних для поширення в Украӥні на 2021 рік. Київ: Мінагрополітики. С. 465-466.

Boscamp-Lasopolski, K. (1963). Moje przelotne miłostki z młoda Bitynka [Rękopis z roku 1789; Opracowanie i wstęp Jerzy Łojek]. Kraków: Literackie. 147 p.

Dunin-Borkowski, J. (1908). Potocki herbu Pilawa. Almanach błękitny: Genealogia żyjących rodów Polskich. Lwow: Nakładem księgarni H. Altenberga; Warszawa: E. Wende i Ska. P. 729-773.

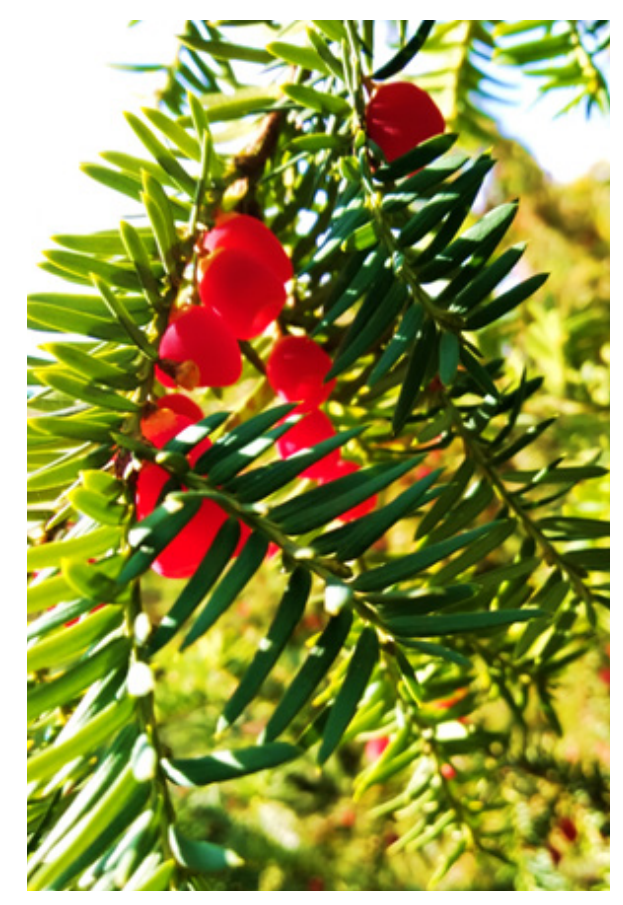

Рис. 9. Плоди Taxus baccata L.

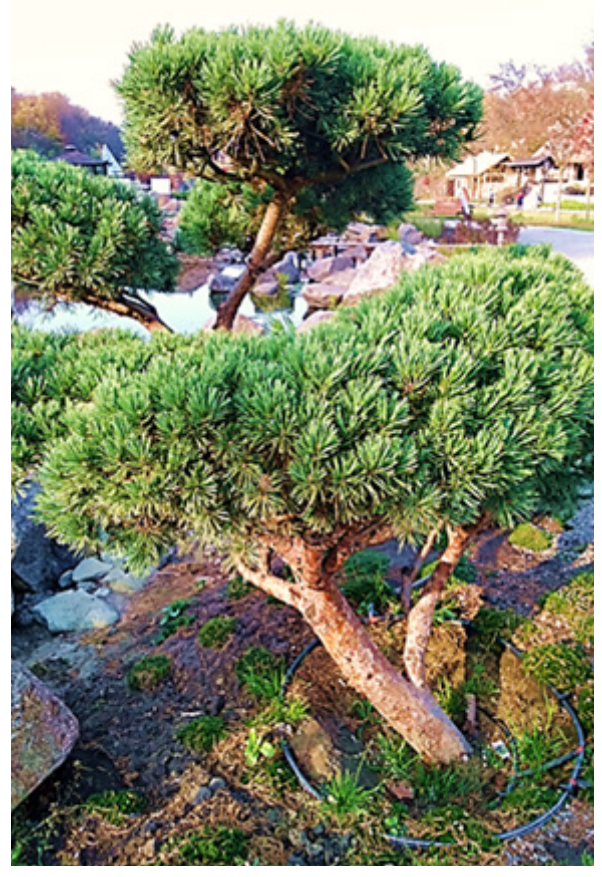

Рис. 10. Грська сосна (Pinus mugo Turra) 
Kosenko, I. S., Balabak, A. F., Sonko, S. P., Balabak, O. A., Balabak, A. V., Opalko, A. I., Denysko, I. L., \& Soroka, L. V. (2019 a). Tolerance of hazelnuts towards unfavorable environmental factors. Ukrainian Journal of Ecology. Vol. 9. No 3. P. 117-125. DOI: https://doi.org/10.15421/40290501.

Kosenko, I., Hrabovyi, V. \& Opalko, A. (2021). Accessibility of National dendrological park "Sofiyivka" of the NAS of Ukraine for people with special needs. Social and educational services for children with disabilities: history, theory and practice: Joint monograph [Ed.: O. O. Kravchenko]. Częstochowa: HARIT. P. 327-332.

Kosenko I. S., Opalko A. I., Balabak O. A., Opalko O. A. \& Balabak A. V. Hazelnut (Corylus domestica Kos. et Opal.) research and breeding at NDP «Sofiyivka» of NAS of Ukraine. Temperate Horticulture for Sustainable Development and Environment. Ecological aspects. [Eds.: Larissa I. Weisfeld, Anatoly I. Opalko, Sarra A. Bekuzarova.]. Oakville; Waretown: Apple Academic Press, 2019 b. Ch. 13. P. 237-267+D, E, F.

Kosenko, I.S., Opalko, O.A., Zagoruiko L. O. \& Opalko, A.I. (2020). Dendrological park "Sofiyivka": Its history and botanic collection. The International Journal of Plant Reproductive Biology. Vol. 12(1). P. 25-33.

Łojek, J. (1995). Dzieje pięknej Bitynki. Opowieść o życiu Zofii Wittowej-Potockiej (1760-1822) [6-e wyd.]. Warszawa: Alfa. 443 p.

Łojek, J. (1998). Stanisław August Poniatowski i jego czasy. Warszawa: Alfa. 229 p.

Themery, T. (1846). Guide de Sophiowka: surnommé la merveille de l'Ukraine, Jardin de la couronne situé près d'Human, dans les colonies militaires. Odessa: A. Braun. 63 p.

Trembecki, S. (1815). Sophiowka: poeme polonais [Trad.: vers francais par le comte de Lagarde]. Vienne: De L'Imprimerie d'Antoine Strauss.. $176 \mathrm{p}$.

Wolszczanowa H. (1972). Potocki: Stanisław Szczęsny, Jósefa Amelia z Mniszchów, Stanisław Septym, Jarosław, Mikołaj. Słownik pracowników ksiqżki polskiej [Ed.: I. Treichel]. Warszawa, Lódż: Panstwowe Wydawnictwo Naukowe. P. 709-710.

УДК 635.9:378.147.091.3

DOI 10.37555/2707-3114.1.2021.247349

\section{Впровадження дидактичних принципів у навчальну дисципліну «Квітникарство та декоративне садівництво»}

Антонеџь М.О., Антонеџь О. А.

Полтавський державний аграрний університет, Полтава. e-mail: Antmarina63@yahoo.com, Apisaaa61@gmail.com

\section{Introduction of didactic principles in the "Floriculture and ornamental gardening" academic subject}

Antonets M. O., Antonets O. A.

Poltava State Agrarian University, e-mail: Apisaaa61@gmail.com

Анотація. Актуальність теми обумовлена пошуком нових дидактичних принџипів і впровадження їх у викладання навчальної дисџипліни «Квітникарство і декоративне садівниџтво» на кафедрі рослинниџтва ПДАУ. Дослідження проводилося у 2019-2021 роках методом включеного спостереження і формуючого експерименту серед здобувачів вищої освіти 2 курсу факультету агротехнологій та екології спеџіальності 201 Агрономія. Впровадження чотирьох дидактичних принџипів, а саме відповідальності, патріотизму, екологічності та естетичного принџипу, у викладання навчальної дисџипліни «Квітникарство і декоративне садівниџтво» сприяє вихованню духовно зрілих, розумних та праџелюбних фахівџів в аграрній сфері України.

Ключові слова: дидактика, принџипи, квітникарство та декоративне садівниџтво, здобувачі виџої освіти. 